Z. Klin. Chem. Klin. Biochem.

11. Jg. 1973 , S. $147-151$

\title{
Measurement of the Rate of Synthesis of Albumin with 14C-Carbonate: A Simplified Method
}

\author{
By J. C. M. Hafkenscheid, S. H. Yap and J. H. M. van Tongeren
}

University of Nijmegen, Department of Medicine, Diilision of Gastro-enterology, St. Radboudziekenbuis, Nijmegen, The Netherlands

(Eingegangen am 12. Oktober/11. Dezember 1972)

\begin{abstract}
A simplified method for the determination of the rate of synthesis of albumin after the i. $\mathbf{v}$. injection of ${ }^{14} \mathrm{C}$-carbonate is described. A number of experiments to check the accuracy of the ${ }^{14} \mathrm{CO}_{2}$ measurements is reported. Good agreement is obtained betwcen the specific activity of urinary urea, measured by means of our method and by the manometric method. Recoveries of 101.9 and $101.1 \%$ respectively are found for ${ }^{14} \mathrm{C}$-urea added to plasma or urine. Endogenously formed ${ }^{14} \mathrm{C}$-urea shows a maximal specific activity $2-3 \mathrm{~h}$ after the i. v. injection of ${ }^{14} \mathrm{C}$-carbonate. Thereafter the specific activity of ${ }^{14} \mathrm{C}$-urea gradually decreases. Enzymic conversion with arginase and urease and analysis with an amino-acid analyser give the same values for the arginine content of an albumin hydrolysate.

Good agreement between the rates of synthesis and catabolism of albumin, determined respectively with ${ }^{14} \mathrm{C}$-carbonate and ${ }^{131} \mathrm{I}$-albumin, was obtained in individual patients. In a group of 6 patients an average rate of synthesis of $10.6 \mathrm{mg} / \mathrm{kg} \cdot \mathrm{h}$ and an average catabolic rate of $9.5 \mathrm{mg} / \mathrm{kg} \cdot \mathrm{h}$ were measured. The difference between this simplified method and the manometric technique lies in a direct measurement of the concentration of urea and arginine in the method described here in contrast to the conversion of urea and arginine to $\mathrm{CO}_{2}$ in the manometric method. Advantages of the simplified method for the determination of the rate of synthesis of albumin are discussed.
\end{abstract}

Es wird eine einfache Methode zur Bestimmung der Synthesegeschwindigkeit von Albumin nach i. v. Injektion von ${ }^{14} \mathrm{C}-\mathrm{Carbonat}$ beschrieben. Dazu wurden verschiedene Untersuchungen zur Prüfung der Genauigkeit der ${ }^{14} \mathrm{CO}_{2}-\mathrm{Messungen} \mathrm{durchgeführt.} \mathrm{Wir} \mathrm{fanden}$ eine gute Ubereinstimmung $z$ wischen unserer und der manometrischen Methode bei der Bestimmung der spezifischen Aktivität des Urinharnstoffs. Es wurden Wiederfindungswerte von 101,9 und $101,1 \%$ erzielt, falls ${ }^{14} \mathrm{C}$-Harnstoff entweder Plasma oder Urin zugefügt wurde. Endogen gebildeter ${ }^{14} \mathrm{C}$-Harnstoff zeigte $2-3 \mathrm{~h}$ nach der $\mathrm{i}$. v. Injektion von ${ }^{14} \mathrm{C}$-Carbonat eine maximale spezifische Aktivität. Danach nahm die spezifische Aktivität des ${ }^{14} \mathrm{C}$-Harnstoffs langsam ab.

Sowohl die enzymatische Umwandlung durch Arginase und Urease als auch die Analyse mittels Aminosäure-Analysator ergaben gleiche Werte für den Arginingehalt eines Albuminhydrolysats. Bei den einzelnen Patienten wurde eine gute Úbereinstimmung zwischen der Synthese- und Abbaurate von Albumin, bestimmt durch die Untersuchung mittels ${ }^{14} \mathrm{C}$-Carbonat bzw. ${ }^{131} \mathrm{~J}$-Albumin, erreicht. Bei 6 Patienten wurde eine durchschnittliche Synthesegeschwindigkeit von $10,6 \mathrm{mg} / \mathrm{kg} \cdot \mathrm{h}$ und eine durchschnittliche Geschwindigkeit für den Abbau von $9,5 \mathrm{mg} / \mathrm{kg} \cdot \mathrm{h}$ gemessen. Der Unterschied zwischen der einfachen Methode und der manometrischen Technik liegt in einer direkten Bestimmung der Konzentration des Harnstoffs und Arginins in der hier beschriebenen Methode im Gegensatz zu der Umwandlung des Harnstoffs und Atginins zu $\mathrm{CO}_{2}$ bei der manometrischen Bestimmung. Die Vorteile der vereinfachten Methode zur Bestimmung der Syntheserate von Albumin werden diskutiert.

Until 1963 the rate of synthesis of albumin was estimated by determining its catabolic rate and assuming the two rates to be equal. The catabolic rate was determined by administering ${ }^{131} \mathrm{I}$-albumin intravenously and measuring daily the plasma and urine ${ }^{131} \mathrm{I}$-activities. When, however, the albumin metabolism is in a steadystate during a short time interval, the rate of synthesis must be determined directly.

A new impetus for measuring albumin synthesis came from an observation of DeLLuVA and WiLson (1) who demonstrated that the $i$. v. injection of ${ }^{14} \mathrm{C}$-carbonate leads to the labelling of the guanidine-C of arginine in proteins produced in the liver. McFarLANE (2) was especially responsible for introducing the use of ${ }^{14} \mathrm{C}$ carbonate for the determination of the rate of synthesis of albumin. The ${ }^{14} \mathrm{C}$-arginine, produced in the liver from ${ }^{14} \mathrm{C}$-carbonate, is the common precursor for ${ }^{14} \mathrm{C}$-urea and the ${ }^{14} \mathrm{C}$-guanidine group of arginine in albumin. The determination of the albumin synthesis with ${ }^{14} \mathrm{C}$-carbonate is based upon the following formula: amount of albumin synthesised in time interval $\left(t_{1}-t_{0}\right)=$

$$
\frac{\text { total radioactivity incorporated into albumin }}{\text { total radioactivity incorporated into urea }}
$$

$X$ amount urea synthesised in time interval $\left(t_{1}-t_{0}\right)$.

The activity of albumin is expressed as the activity of the guanidine- $C$ of the arginine in albumin.

Different methods are described for the determination of the specific activities of ${ }^{14} \mathrm{C}$-urea and of the ${ }^{14} \mathrm{C}$ guanidine group of arginine in albumin. McFarLANE (2) and TAvill et al (3) determined these specific activities manometrically. In a second method, introduced by BIANCHI and MARIANI (4), urea is precipitated, whereupon the weight and radioactivity of the resulting dixanthydryl urea are determined. With both these methods the amount and radioactivity of $\mathrm{CO}_{2}$ or urea from the same sample are measured. RothsCHILD 
et al (5) determined the amount and the radioactivity of urea in two aliquots of the ${ }^{14} \mathrm{C}$-urea sample, but these authors gave no further details.

We wish to report here a simple and reliable method for measuring the rate of synthesis of albumin with the aid of an incubation flask as described by Fox (6). For 6 patients the rate of synthesis thus determined is compared with the catabolic rate of albumin determined by means of ${ }^{131} \mathrm{I}$-albumin.

\section{Materials and Methods}

The rates of synthesis and catabolism of albumin were determined in 6 patients, who all appeared to be in a steady state so far as their albumin metabolism was concerned. Clinical data and diagnosis of these patients are summarized in Table 3.

Patients received a normal diet $(60 \mathrm{~g}$ of protein, $60 \mathrm{~g}$ of fat, $250 \mathrm{~g}$ of carbohydrate; about 1800 calories) until the evening before the investigation. In order to reduce bacterial urease activity in the colon $1 \mathrm{~g}$ neomycin was given every $6 \mathrm{~h}$ for at least 2 days prior to the study. The thyroid gland was blocked with Lugol solution starting 2 days before the investigation and continuing for 3 weeks during the determination of the catabolic rate of ${ }^{131}$ I-albumin.

Labelling of albumin with ${ }^{131} \mathrm{I}$ was performed by means of ${ }^{131} \mathrm{ICl}$ as described by McFariane (7).

After the i. v. injection of $50 \mu \mathrm{Ci}$ 131 I-albumin, $6 \mathrm{ml}$ blood samples were taken after 16,20,24 and $28 \mathrm{~min}$ for the determination of the plasma volume. The catabolic rate of albumin is determined by collecting blood samples over a 3 -week period and by measuring the residual radioactivity in a whole body counter. The catabolic rate is calculated according to a modification of the method of Pearson et al (8).

For the study of albumin synthesis, $100-200 \mu \mathrm{Ci} \mathrm{Na}{ }_{2}{ }^{14} \mathrm{CO}_{3}$ was injected $i$. v. The specific activity of endogenously formed ${ }^{14} \mathrm{C}$ urea was determined in a $10 \mathrm{ml}$ blood sample collected $7 \mathrm{~h}$ after the ${ }^{14} \mathrm{C}$-carbonate injection. After $7 \mathrm{~h}$ an additional $50 \mathrm{ml}$ blood sample was obtained for measurement of the specific activity of the ${ }^{14} \mathrm{C}$-guanidine group of arginine in albumin. At the same time a $6 \mathrm{ml}$ blood sample was taken for the determination of ${ }^{131} \mathrm{I}$-albumin. One to three days after the investigation of the albumin synthesis $5-10 \mu \mathrm{Ci}{ }^{14} \mathrm{C}$-urea was injected i. $v$. for determination of the disappearance rate of urea. For this purpose $5 \mathrm{ml}$ blood samples were removed $1.5,3,4,5$ and $7 \mathrm{~h}$ following the ${ }^{14} \mathrm{C}$-urea injection.

For the determination of the specific activity of the endogenously formed ${ }^{14} \mathrm{C}$-urea, $0.5 \mathrm{ml}$ plasma was added to a vial (Fig. 1) containing urease (urea-amidohydrolase EC $3.5 .1 .5 ; 1 \mathrm{mg} / \mathrm{ml}$, Tris$\mathrm{HCl}(0.1 \mathrm{~mol} / \mathrm{l})$ buffer $\mathrm{pH} 7.5)$. The assembled tube contained $0.5 \mathrm{ml}$ of a $1: 2$ mixture of methanol and 2-phenylethylamine to bind released ${ }^{14} \mathrm{CO}_{2}$. At the same time $0.5 \mathrm{ml}$ of plasma was

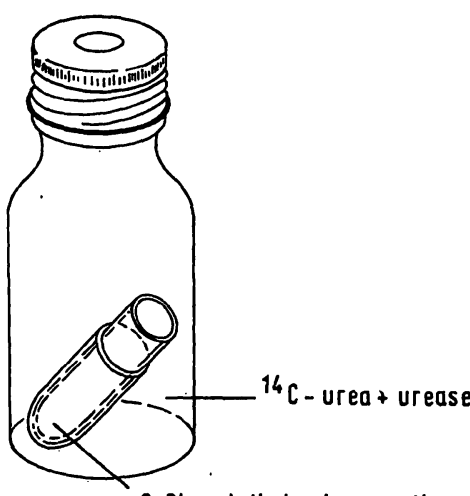

2-Phenylethylamine + methanol

Fig. 1

Assembled incubation flask for $\mathrm{CO}_{3}$ determination added to a vial containing Tris- $\mathrm{HCl}$ buffer without urease to determine the amount of $\mathrm{H}^{14} \mathrm{CO}_{3}^{-}$. After incubation for $1.5 \mathrm{~h}$ at $37^{\circ} \mathrm{C}, 0.5 \mathrm{ml} 2 \mathrm{~mol} / 1 \mathrm{HCl}$ was introduced by a syringe through the stopper of the vial. Incubation for $1 \mathrm{~h}$ at $37^{\circ} \mathrm{C}$ released all $\mathrm{CO}_{2}$, which was then bound in the methanol-phenylethylamine mixture. The inner tube and contents were transferred to a scintillator vial containing $9.5 \mathrm{ml}$ of toluene scintillator and counted in a liquid scintillation counter (Nuclear-Chicago).

The determination of the specific activity of urinary ${ }^{14} \mathrm{C}$-urea was carried out in the same manner, except that the determination of $\mathrm{H}^{14} \mathrm{CO}_{3}^{-}$was omitted.

Plasma $(15 \mathrm{ml})$ was saturated to $50 \%$ with $\left(\mathrm{NH}_{4}\right)_{2} \mathrm{SO}_{4}$ for the isolation of albumin. The precipitate was separated by centrifugation $(30.000 \mathrm{~g} ; 20 \mathrm{~min})$. The supernatant was brought to $\mathrm{pH} 4.5$ by adding slowly $1 \mathrm{~mol} / 1 \mathrm{HCl}$ and the albumin thus precipitated was collected by centrifugation. After redissolving the albumin precipitate in $10 \mathrm{ml}$ of water and bringing the $\mathrm{pH}$ to 7.0 with $1 \mathrm{~mol} / 1 \mathrm{NaOH}$, the entire procedure was repeated. The albumin fraction $(25 \mathrm{ml})$ was dialysed overnight. After an adapted dilution (about $400 \mathrm{mg}$ albumin in $75 \mathrm{ml}$ water) the albumin was hydrolysed in sealed tubes in $75 \mathrm{ml} 6 \mathrm{~mol} / 1 \mathrm{HCl}$ at $110^{\circ} \mathrm{C}$ for $15 \mathrm{~h}$ Excess $\mathrm{HCl}$ was removed by evaporation and neutralisation with an aqueous suspension of De-acidite $\mathrm{FF}$ ( $\mathrm{HCO}_{3}^{-}$form). The resin was removed by suction on a BüCHNER funnel. After concentration to $7 \mathrm{ml}$ by evaporation the total hydrolysate was placed on a column $(18 \times 1.5 \mathrm{~cm})$ of mixed resin (equal quantities of $25 \mathrm{ml}$ of De-acidite $\mathrm{FF}$ in $\mathrm{Cl}^{-}$and in $\mathrm{OH}^{-}$form). The arginine was eluted by washing with $100 \mathrm{ml}$ water. The fractions (about $10 \mathrm{ml}$ ) were neutralized and identified with ninhydrin. The arginine fraction was concentrated to $3 \mathrm{ml}$ and an aliquot converted in a vial (see Fig. 1) with arginase ( $\mathrm{L}$-arginine amidinohydrolase EC $3.5 .3 .1 ; 1 \mathrm{mg} / \mathrm{ml}$ maleic acid $(2 \mathrm{~mol} / \mathrm{l})+\mathrm{MnSO}_{4}$ $(50 \mathrm{mmol} / \mathrm{l}) \mathrm{pH} 7.0$, preactivated $5 \mathrm{~h}$ at $\left.37^{\circ} \mathrm{C}\right)$ overnight at $37^{\circ} \mathrm{C}$. Urease was added and ${ }^{14} \mathrm{CO}_{2}$ determined as described in the preceding section.

The disappearance rate of urea after the $i$. $v$. administration of ${ }^{14} \mathrm{C}$-urea was determined by deproteinising $1 \mathrm{ml}$ plasma with $2.5 \mathrm{ml}$ trichloro-acetic acid $(100 \mathrm{~g} / \mathrm{l})$ and adding $1 \mathrm{ml}$ supernatant obtained after centrifugation to $9 \mathrm{ml}$ of dioxan scintillator.

Arginine was determined by the colorimetric method of SAKAGUCHI (9) as described by Albanese and Frankston (10). Urea was determined after conversion with urease by the phenol$\mathrm{NaClO}$ method (11).

Dioxane scintillator was prepared by dissolving $60 \mathrm{~g}$ naphthalene, $20 \mathrm{ml}$ ethyleneglycol, $4 \mathrm{~g}$ PPO (2,5-diphenyloxazole) and $0.2 \mathrm{~g}$ POPOP (2.2'-p-phenylene bis (5-phenyloxazole)) in a mixture of $100 \mathrm{ml}$ methanol and $850 \mathrm{ml}$ dioxane. Toluene scintillator was prepared by adding $5 \mathrm{~g}$ PPO and $0.5 \mathrm{~g}$ POPOP to $1000 \mathrm{ml}$ toluene.

All determinations were carried out in duplicate.

$\mathrm{Na}_{2}{ }^{14} \mathrm{CO}_{3}$ and ${ }^{14} \mathrm{C}$-urea were obtained from the Radiochemical centre, Amersham and ${ }^{131}$ as $\mathrm{Na}^{131}$ I from Hoechst $\mathrm{AG}$ Frankfurt. All reagents were analytical grade.

The calculation of the rate of albumin synthesis can be made from the following principle:

spec. act. of synthesised albumin in time interval $\left(t_{1}-t_{0}\right)=$ spec. act. of synthesised urea in time interval $\left(t_{1}-t_{0}\right)$.

Then:

synthesised albumin in time interval $\left(t_{1}-t_{0}\right)=$ $\frac{\text { spec. act. of albumin at } t_{0}}{\text { spec. act. of urea at } t_{0}} \times$ fractional synthesis rate of urea $X$ plasma albumin pool.

Specific activity of urea is expressed as $\frac{\mathrm{pCi}}{\mu \mathrm{mol} \text { urea }}$.

Specific activity of albumin is expressed as spec. act. of the guanidine- $C$ of the arginine in albumin $\left(\frac{\mathrm{pCi}}{\mu \mathrm{mol} \text { arginine }}\right)$.

Spec. act. of albumin at $t_{0}$ : spec. act. of albumin at $t_{1}$ extrapolated to $t_{0}$ with the ${ }^{131}$ I-albumin disappearance tate. 
Spec., act. of urea at $t_{0}$ : spec. act. of endogenously formed ${ }^{14} \mathrm{C}$ urea at $t_{1}$ extrapolated to $t_{0}$ with the ${ }^{14} \mathrm{C}$-urea (exogenous) disappearance rate.

Fractional synthesis rate of urea $=$ fractional disappearance rate of urea

$$
=\frac{0.693}{t_{1 / 2} \text { of the }{ }^{14} \mathrm{C} \text {-urea (exogenous) disappearance rate }} .
$$

Plasma albumin pool: plasma albumin concentration $\times$ plasma volume.

\section{Results}

A number of experiments was performed to test the reliability of the method of Fox (6) for the measurement of ${ }^{14} \mathrm{CO}_{2}$.

The total radioactivity of standard ${ }^{14} \mathrm{C}$-urea is linear with respect to the amount of the ${ }^{14} \mathrm{C}$-urea solution (Fig. 2). The reproducibility of the ${ }^{14} \mathrm{CO}_{2}$ determination is $2.5 \%$ expressed as the relative standard deviation for 9 determinations of ${ }^{14} \mathrm{C}$-urea.

Figure 3 demonstrates, that 0.5 to $1.0 \mathrm{ml}$ of a $1: 2$ mixture of methanol and 2-phenylethylamine is suf-

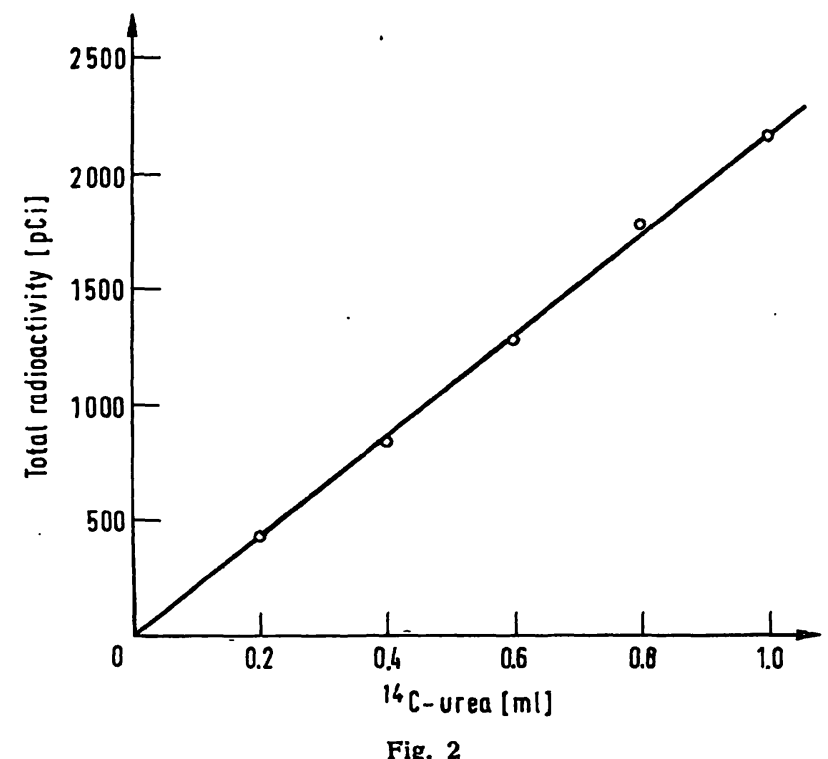

Total radioactivity as a function of the amount of ${ }^{14} \mathrm{C}$-urea

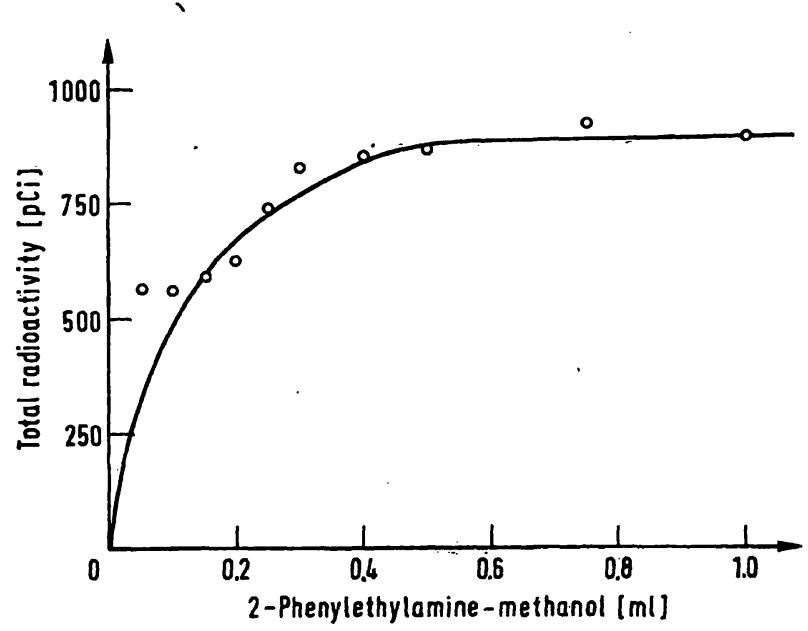

Fig. 3

Influence of increasing amounts of methanol-base (methanol-2-phenylethylamine; $1: 2$ ) on the determination of total radioactivity of a
standard "C-urea solution
Tab. 1

Recovery of standard "C-urea added to urine or plasma

\begin{tabular}{cccc}
\hline Urine & Added & $\begin{array}{c}\text { Determined } \\
\text { value } \\
(\mathrm{pCi})\end{array}$ & Recovered \\
$(\mathrm{pCi})$ & $(\mathrm{pCi})$ & 2241 & $(\%)$ \\
\hline 397 & 1757 & 4279 & 104.0 \\
397 & 3919 & 3568 & 99.2 \\
1690 & 1757 & 5484 & 103.7 \\
1690 & 3919 & Mean value & 101.1 \\
& & & \\
\hline & & Determined & Recovered \\
\hline Plasma & Added & value & $(\mathrm{pCi})$ \\
$(\mathrm{pCi})$ & $(\mathrm{pCi})$ & 539 & $(\%)$ \\
\hline 51 & 482 & 545 & 100.9 \\
54 & 482 & 621 & 101.8 \\
121 & 482 & Mean value & 101.9 \\
\hline
\end{tabular}

ficient to bind the liberated $\mathrm{CO}_{2}$ from a solution containing $5 \mu \mathrm{mol}$ urea.

The recovery of ${ }^{14} \mathrm{C}$-urea, added to urine or plasma, is shown in Table 1 . The recovery for urine is $101.0 \%$, for plasma $101.9 \%$.

The specific activity of urinary urea from a normal individual, measured according to the manometric technique and the method described here, is shown in Figure 4. There is an increase of the specific activity of ${ }^{14} \mathrm{C}$-urea during the $3-4 \mathrm{~h}$ after the $\mathrm{i}$. v. injection of ${ }^{14} \mathrm{C}$-carbonate. Thereafter a gradual decrease following a single exponential function takes place. These results agree with those of WochNer et al (12).

Figure 5 demonstrates the decrease in $\mathrm{H}^{14} \mathrm{CO}_{3}^{-}$concentration in venous plasma after the $i$. $v$. injection of ${ }^{14} \mathrm{C}$-carbonate in 2 patients. The initial decrease is very rapid and after $7-9 \mathrm{~h}$ only $0.1 \%$ of ${ }^{14} \mathrm{C}$-carbon is present as $\mathrm{H}^{14} \mathrm{CO}_{3}^{-}$. The half-time values $(\mathrm{t} t / 2)$ for the lower part of the curve are $75 \mathrm{~min}$ and $105 \mathrm{~min}$, which agree with the values obtained by JoNEs et al (13)

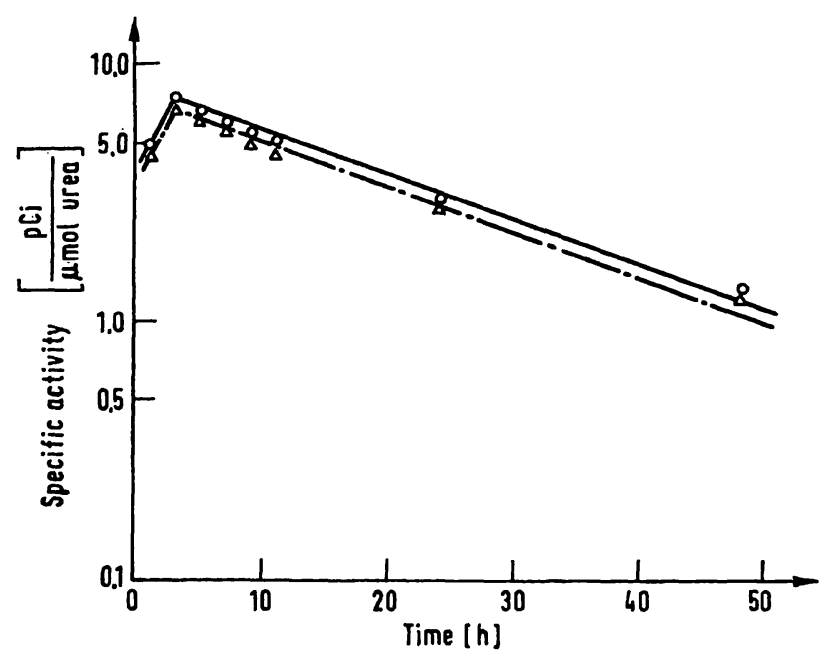

Fig. 4

Comparison of urinary specific activity of "C-urea measured with the manometric method $(O-O)$ and the described method $(\Delta-\cdot-\Delta)$. 


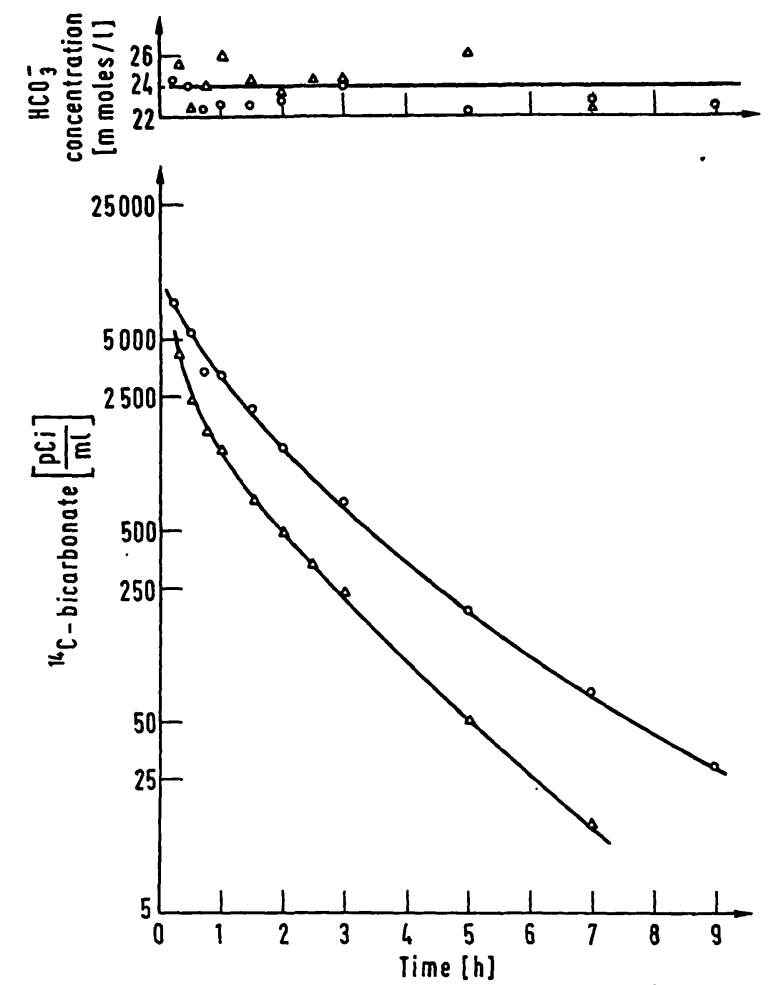

Fig. 5

Disappearance rate of $\mathrm{H}^{14} \mathrm{CO}_{3}^{-}$in plasma for 2 persons after i. v. in jection of ${ }^{14} \mathrm{C}$-carbonate. $\mathrm{H}^{14} \mathrm{CO}_{3}^{-}$determination was carried out as the determination of ${ }^{14} \mathrm{C}$-urea; urease was omitted

Total $\mathrm{HCO}_{3}^{-}$concentration was determined according to a titrimetric method

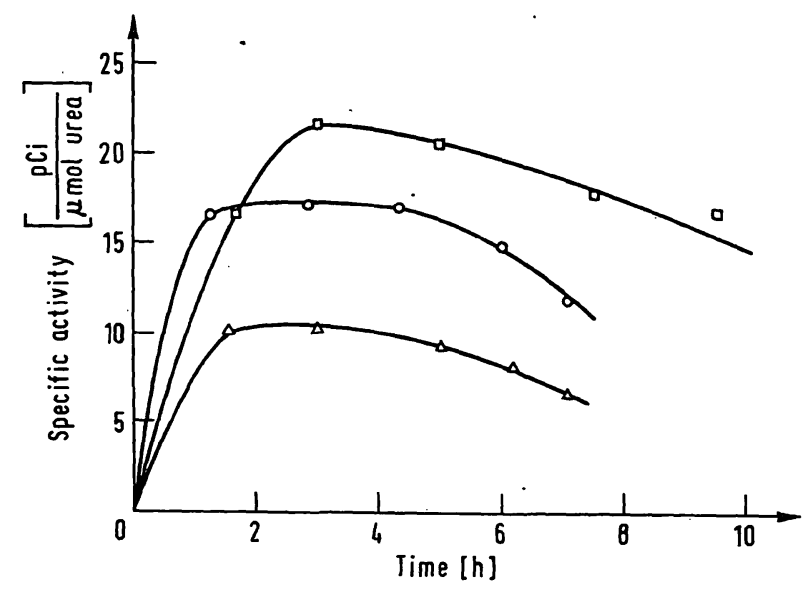

Fig. 6

Specific activity of endogenous ${ }^{1+} \mathrm{C}$-urea for 3 persons after i. $v$. injection of ${ }^{1 "} \mathrm{C}$-carbonate. $10 \mathrm{ml}$ blood samples are taken after $1.5,3$, 4,5 and $7 \mathrm{~h}$ after the ${ }^{14} \mathrm{C}$-carbonate injection

with the manometric technique. The $\mathrm{HCO}_{3}^{-}$concentration in plasma is practically constant (upper part of Fig. 5).
Tab. 2

Determination of arginine from an albumin hydrolysate by several methods

\begin{tabular}{llcc}
\hline & Determination method & Added enzyme & $\begin{array}{c}\mu \text { moles } \\
\text { arginine }\end{array}$ \\
\hline 1 & Amino-acid analysis & - & 32.0 \\
2 & SAKAGUCHI $(9,10)$ & - & 34.6 \\
3 & Urea & arginase & 35.1 \\
4 & $\mathrm{NH}_{3}$ & arginase + itease & 38.0 \\
5 & $\mathrm{CO}_{2}$ & arginase + urease & 34.8 \\
\hline
\end{tabular}

Figure 6 shows the time-curve for the endogenously formed ${ }^{14} \mathrm{C}$-urea in plasma after the $i$. v. injection of ${ }^{14} \mathrm{C}$-carbonate. During the first $2-3 \mathrm{~h}$ after the i. $\mathrm{v}$. injection of ${ }^{14} \mathrm{C}$-carbonate there is a rapid rise of the specific activity of ${ }^{14} \mathrm{C}$-urea followed by a slower fall caused by urinary excretion. These curves are similar to those obtained by the manometric technique (3).

According to BraNCHr et al (14) the conversion of the guanidine group of arginine in an albumin hydrolysate with arginase and urease to $\mathrm{CO}_{2}$ and $\mathrm{NH}_{3}$ is incomplete. BraNCHI et al (14) have shown, that the hydrolysis of urea by urease is nearly complete, when the enzyme reacts directly, but that the degree of hydrolysis may decrease to only $30 \%$, when urease is added after the action of arginase on the albumin hydrolysate, despite a ten fold increase of the urease concentration. Therefore, we have investigated the amount of $\mathrm{CO}_{2}$ and $\mathrm{NH}_{3}$ liberated after the enzymic action of arginase and urease on arginine from an albumin hydrolysate. The amount of arginine was also determined by amino-acid analysis and by the method of SAKAGuchI $(9,10)$. Table 2 shows, that 32.0 and $34.6 \mu$ moles arginine were measured respectively according to these two methods. After the action of arginase $35.1 \mu$ moles urea were liberated. Virtually complete liberation of $\mathrm{CO}_{2}$ and $\mathrm{NH}_{3}$ was obtained after the enzymic action of arginase and urease, in contrast to the results of BrANCHI et al (14).

Table 3 compares the synthetic rates of albumin, determined by our method after the i. v. injection of ${ }^{14} \mathrm{C}$-carbonate, with the catabolic rates measured simultaneously with 131I-albumin. There is good agreement for the 6 patients, whose albumin metabolism is in a steady state. Similarly good agreement was reached between the synthetic and catabolic rates of albumin as previously described by TAviLL et al (3), Wochner et al (12) and BIANCHI et al (15) (Tab. 4).

Tab. 3

Rates of albumin synthesis and degradation

\begin{tabular}{|c|c|c|c|c|c|c|c|c|c|c|c|c|}
\hline \multirow{3}{*}{ Patient } & \multirow{3}{*}{ Sex } & \multirow{3}{*}{ Age } & \multirow{3}{*}{ Diagnosis } & \multirow{3}{*}{$\begin{array}{l}\text { Weight } \\
\text { (kg) }\end{array}$} & \multirow{3}{*}{$\begin{array}{l}\text { Height } \\
\text { (m) }\end{array}$} & \multirow{3}{*}{$\begin{array}{c}\text { Plasma } \\
\text { volume } \\
\text { (ml) }\end{array}$} & \multirow{3}{*}{$\begin{array}{l}\text { Serum } \\
\text { albumin } \\
(\mathrm{g} / \mathrm{l})\end{array}$} & \multirow{3}{*}{$\begin{array}{c}t_{1} / 2 \text { exo- } \\
\text { genous } \\
\text { urea }\end{array}$} & \multicolumn{4}{|c|}{ Rate of albumin } \\
\hline & & & & & & & & & degrac & ation & synt & esis \\
\hline & & & & & & & & & $(\mathrm{mg} / \mathrm{kg} \cdot \mathrm{h})$ & (g/day) & $(\mathrm{mg} / \mathrm{kg} \cdot \mathrm{h})$ & (g/day) \\
\hline 1 & $0^{\prime \prime}$ & 60 & Terminal ileitis & 65.8 & 1.64 & 2670 & 43.9 & 12.85 & 10.8 & 17.0 & 12.5 & 19.7 \\
\hline 2 & $0^{\circ}$ & 26 & Control & 86.0 & 1.83 & 3010 & 48.7 & 10.00 & 6.7 & 13.8 & 6.9 & 14.2 \\
\hline 3 & $0^{\prime \prime}$ & 53 & Oesophagitis & 74.4 & 1.62 & 2390 & 43.4 & 9.33 & 7.6 & 13.6 & 8.0 & 14.3 \\
\hline 4 & $0^{*}$ & 54 & Ulcerative gastritis & 51.1 & 1.72 & 2630 & 40.2 & 9.25 & 11.9 & 14.6 & 14.2 & 17.4 \\
\hline 5 & 우 & 59 & Chronic hepatitis & 55.3 & 1.66 & 2740 & 42.6 & 8.25 & 9.4 & 12.4 & 11.3 & 15.0 \\
\hline 6 & $\sigma^{\circ}$ & 59 & Sprue syndrome & $=57.1$ & 1.68 & 2770 & 42.1 & 12.00 & 10.3 & 14.1 & 10.9 & 14.9 \\
\hline
\end{tabular}


Tab. 4

Comparison of rates of albumin synthesis and degradation in controls and patients in a steady state

\begin{tabular}{lccc}
\hline & $\begin{array}{c}\text { Number } \\
\text { of persons }\end{array}$ & $\begin{array}{c}\text { Albumin } \\
\text { degradation } \\
\text { (191I-albumin) } \\
\mathrm{mg} / \mathrm{kg} \cdot \mathrm{h}\end{array}$ & $\begin{array}{c}\text { Albumin } \\
\text { synthesis } \\
\left({ }^{14} \mathrm{C} \text {-albumin }\right) \\
\mathrm{mg} / \mathrm{kg} \cdot \mathrm{h}\end{array}$ \\
\hline TAVILL et al (3) & 12 & 6.6 & 6.4 \\
WochNeR et al (12) & 6 & 6.1 & 5.8 \\
BIANCHI et al (15) & 8 & 7.9 & 7.9 \\
This study & 6 & 9.5 & 10.6 \\
\hline
\end{tabular}

\section{Discussion}

If the albumin metabolism is in a steady state, the rate of albumin synthesis will be equal to the catabolic rate. Disadvantages of the determination of the catabolic rate with ${ }^{131}$ I-albumin are its long duration (about $2-3$ weeks) and the requirement for a steady state albumin metabolism during that period. Direct measurement of the synthetic rate does not have these disadvantages. Only $7 \mathrm{~h}$ elapse from the moment of ${ }^{14} \mathrm{C}$-carbonate injection to the collection of the last blood sample. There is no requirement for a steady state metabolism for a long period.

In addition to other factors e. g. plasma volume and albumin and urea concentration in plasma, the specific activity of plasma urea and of the guanidine-C of arginine in albumin must be determined. MCFARIANE (2) and TAviLL et al (3) have introduced a manometric technique, in which the amount of $\mathrm{CO}_{2}$ liberated from a sample was measured and this amount was counted in a liquid scintillation counter. BIANCHI et al (4) precipitate urea as dixanthydryl urea, whereupon the precipitate is weighed and counted. These both methods are laborious and time-consuming. For the measurement of the specific activity of ${ }^{14} \mathrm{C}$-urea Rothschild et al
(5) determined the urea concentration and the radioactivity of the sample separately.

In this paper a simplified method is described for determining the specific activity of urea by trapping the $\mathrm{CO}_{2}$ in 2-phenylethylamine and by measuring the urea concentration according to a routine procedure. Since in our method the radioactivity and the urea concentration are determined in two aliquots of the same sample, it is important to know that the enzymic conversion of arginine and urea are quantitative. The action of urease on urea is quantitative, because a very good recovery of added ${ }^{14} \mathrm{C}$-urea is obtained, when ${ }^{14} \mathrm{C}$-urea is added to plasma or urine. Also the conversion of arginine from an albumin hydrolysate with arginase and urease is nearly $100 \%$. Because this enzymic conversion is quantitative, it is possible to determine the rate of synthesis of albumin by this simplified method.

For 6 patients the agreement between the rate of synthesis and the catabolic rate of albumin was good. This close agreement has also been observed by other authors $(3,12,15)$.

The manometric method is laborious, complicated and time-consuming. It demands much blood. With our simplified method the determination is less timeconsuming, it takes only $25 \%$ of the time required by the manometric technique, and the amount of blood required can be reduced by a half.

\section{Acknowledgement}

This work was supported by a grant from the Foundation for Fundamental Medical Research (FUNGO).

The authors wish to thank Dr. J. M. F. TRIJBELs for performing the amino-acid analysis and for valuable discussions and Prof. Dr. S. L. Bontrng for reading the manuscript. The skillful technical assistance of Miss R. H. Selten and Miss M. P. C. HECTORs is gratefully acknowledged.

\section{References}

1. Delluva, A. M. \& Wilson, D. W. (1946), J. Biol. Chem. 166, 739-746. - 2. MCFArLANe, A. S, (1963), Biochem. J. 89, 277-290. - 3. Taviri, A. S., Craigie, A. \& Rosenoer, V. M. (1968), Clin. Sci. 34, 1-28. - 4. Binnchi, R. \& Mariani, G. (1969), J. Nucl. Biol. Med. 13, 167-171. - 5. Rothschild, M. A., Oratz, M., Mongelit, J. \& Schreiber, S. S. (1968), J. Clin. Invest. 47, 2591-2599. - 6. Fox, R. M. (1971), Anal. Biochem. 41, 578-580. - 7. MCFARLANE, A. S. (1956), Biochem. J. 62, 135-143. - 8. Pearson, J. D., Veall, N. \& Vetter, H. (1958), in Radioaktive Isotope in Klinik und Forschung (FELLINGER, K. \& Verter, H. ed. Bd. III, S. 290-297) Urban \& Schwarzenberg; München-Berlin. - 9. SakaguchI, S. (1925), J. Biochem.
5, 133-142. - 10. Albanese, A. A. \& Frankston, J. E. (1945), J. Biol. Chem. 159, 185-194. - 11. Jansen, A. P., Peters, K. A. \& Zelders, T. (1970), Clin. Chim. Acta 27, 125-132. 12. Wochner, R. D., Weissman, S. M., WaldmanN, T. A., Houston, D. \& BerLIN, N. I. (1968), J. Clin. Invest. 47, 971-982. 13. Jones, A. E., Craigie, A., Tavinl, A. S., Simon, W. \& Rosenoer, V. M. (1968), Clin. Sci. 35, 553-564. - 14. Bianchr, R., Donato, L., Mancini, P., Mariani, G., Pilo, A. \& Vitek, F. (1970), in Plasma Protein Metabolism (Rothschild, M. A. \& Waldman, T. ed.) S. 25-49, Academic Press; New York and London. - 15. Bianchi, R., Mariani, G. \& Pilo, A. (1970), J. Nucl. Biol: Med. 14, 136-144.

\author{
Dr. J. C. M. Hafkenscheid \\ University of Nijmegen \\ Department of Medicine \\ Division of Gastro-enterology \\ St. Radboudziekenhuis \\ Nijmegen \\ The Netherlands
}

